\title{
KECERNAAN SERAT KASAR DAN BETN (BAHAN EKSTRAK TANPA NITROGEN) RANSUM KOMPLIT BERBASIS TEBON JAGUNG PADA SAPI PERANAKAN ONGOLE
}

\author{
Christanto Aling, R. A. V. Tuturoong*, Y. L. R. Tulung, Merci R. Waani
}

Fakultas Peternakan Universitas Sam Ratulangi Manado, 95115

\begin{abstract}
ABSTRAK
Penelitian ini bertujuan untuk mengetahui kecernaan Serat Kasar dan BETN ransum komplit pada sapi PO yang menggunakan tebon jagung, rumput raja dan konsentrat. Penelitian ini dilakukan dengan menggunakan 14 ekor sapi PO berumur 1,5-2 tahun, dengan bobot badan $180 \mathrm{~kg}-250 \mathrm{~kg}$. Menggunakan analisis Uji $\mathrm{T}$ (keragaman yang tidak sama) yang terdiri dari 2 perlakuan dengan 7 ulangan. Perlakuan yang digunakan adalah : $\mathrm{Ra}=$ tebon jagung $50 \%$ + konsentrat $50 \%$ dan $\mathrm{Rb}$ $=25 \%$ tebon jagung $+25 \%$ rumput raja + $50 \%$ konsentrat. Hasil penelitian menunjukkan bahwa konsumsi serat kasar berbeda tidak nyata $(\mathrm{P}>0,05)$ antara perlakuan $\mathrm{Ra}$ dan perlakuan $\mathrm{Rb}$, kecernaan serat kasar perlakuan $\mathrm{Rb}$ sangat nyata $(\mathrm{P}<0,01)$ lebih tinggi dibanding perlakuan Ra. Konsumsi dan Kecernaan BETN perlakuan $\mathrm{Rb}$ nyata $(\mathrm{P}<0,05)$ lebih tinggi dibanding perlakuan Ra. Berdasarkan hasil penelitian ini dapat disimpulkan bahwa pemberian ransum komplit berbasis tebon jagung dan rumput raja (Pennisetum purpupoides) pada sapi PO dengan komposisi $50 \%$ konsentrat, $25 \%$ tebon jagung dan $25 \%$ rumput raja meningkatkan konsumsi BETN, kecernaan serat kasar dan kecernaan BETN.
\end{abstract}

Kata Kunci : serat kasar, BETN, tebon jagung, rumput raja, sapi PO.

\footnotetext{
*Korespondensi (corresponding author)

Email : ronny.tuturoong@yahoo.com
}

\section{ABSTRACT}

DIGESTIBILITY OF CRUDE FIBER AND NNFE (NON NITROGEN FREE EXTRACT) COMPLETE FEED BASED ON CORN FORAGE ON ONGOLE CROSSBREED CATTLE. This Research was conducted to evaluate digestibility of crude fiber and NNFE (non nitrogen free extract) complete feed based on corn forage and king grass on ongole crossbreed cattle. The total of 14 ongole crossbreed cattle at age of 1,5-2 years old with the body weight of $180-250$ kilogram were used in this study. The completely using the analysis t-Test (Two-Sample Assuming Unequal Variences) randomized design involving 2 treatments and 7 replications in each treatment was applied at the experimental unit. The treatments of this research were consisted of $\mathrm{Ra}=$ corn forage $50 \%+$ concentrate $50 \%$ and $\mathrm{Rb}=$ corn forage $25 \%+$ king grass $25 \%+$ concentrate $50 \%$. The results of this research showed that consumption of crude fiber was not significantly $(\mathrm{P}>0,05)$ but digestibility of crude fiber was very significantly $(\mathrm{P}<0.01)$. Digestibility of NNFE was significantly $(\mathrm{P}<0.05)$. Based on the result of this study can be concluded that the complete feed based on corn forage and king grass on ongole crossbreed cattle composition $50 \%$ consentrate $+25 \%$ corn forage $+25 \%$ king grass increase consumption of NNFE, digestibility of Crude fiber and digetibility of NNFE.

Key Words: crude fiber, NNFE, corn forage, ongole crossbreed cattle. 


\section{PENDAHULUAN}

Konsumsi daging di Indonesia terus mengalami peningkatan namun, peningkatan tersebut tidak diimbangi dengan produksi daging yang memadai sehingga impor daging selalu dilakukan untuk memenuhi kebutuhan daging nasional. Meningkatnya jumlah penduduk serta pendapatan perkapita masyarakat Indonesia membuat pola konsumsi daging sapi juga meningkat yang berdampak pada pertambahan kebutuhan daging sapi. Ketersediaan daging sapi dalam negeri belum mampu memenuhi kebutuhan masyarakat. Produksi daging sapi di dalam negeri pada tahun 2017 tercatat berjumlah 486,32 ton, tetapi kebutuhan di dalam negeri mencapai 704, 855 ton/tahun (BPS, 2017). Salah satu faktor penting penyebab rendahnya populasi dan produktivitas sapi potong adalah rendahnya kualitas pakan.

Sumber pakan utama ternak ruminansia di Indonesia adalah hijauan pakan dan limbah pertanian. Tebon jagung dan Rumput Raja (Pennisetum purpupoides) merupakan sumber pakan lokal yang potensial dan dimanfaatkan oleh peternak. Menurut Rukmana, (2005) disitasi oleh Nasriya et al. (2016) bahwa produksi rumput raja cukup tinggi, yaitu 200-250 ton/hektar/tahun. Rumput Raja mempunyai kandungan serat kasar 25,48\%, protein kasar 11,68\%, Energi metabolisme
2070 kkal/kg (Rumiyati, 2008), NDF 76,22\% dan ADF 46,75\% (Siswanto et al., 2016). Tebon jagung digunakan sebagai pakan ternak karena produksinya tinggi dalam waktu yang singkat dan mempunyai nilai nutrisi yang baik, dengan kandungan protein kasar 12,06\%, serat kasar 25,2, Energi Metabolisme $2350 \mathrm{kkal} / \mathrm{kg}$ (Erna dan Sarjiman, 2007), NDF 70,01\% dan ADF 43,16\% (Siswanto et al., 2016). Selanjutnya Soeharsono dan Sudaryanto (2006) menyatakan bahwa tebon jagung adalah seluruh tanaman jagung termasuk batang, daun dan buah jagung muda yang umumnya dipanen pada umur tanaman 4565 hari. Pemberian hijauan tidak cukup untuk memenuhi kebutuhan nutrisi ternak ruminansia sehingga perlu ditambahkan pakan penguat seperti konsentrat yang merupakan pakan yang mengandung protein kasar dan energi yang cukup dengan kadar serat kasar yang relatif rendah dan mudah dicerna. Pemberian pakan komplit dapat meningkatkan pertambahan berat badan dan berpengaruh terhadap harga jual sapi (Tulung et al., 2020)

Karbohidrat untuk pakan dibagi ke dalam dua golongan yaitu serat kasar dan bahan ekstrak tanpa nitrogen (BETN). Ternak ruminansia dapat memanfaatkan sumber karbohidrat berasal dari hijauan yang tidak dapat dimanfaatkan nonruminansia. Sumber karbohidrat tersebut, menurut Preston dan Leng (1987), berupa 
selulosa, hemiselulosa dan pektin yang berikatan dengan lignin yang ada pada sel tanaman. Adanya struktur tersebut dalam tanaman menjadikannya sebagai sumber utama serat kasar yang juga dibutuhkan bagi ternak ruminansia. Faktor bahan pakan, khususnya serat kasar selain menentukan kecernaan juga menentukan laju kecepatan aliran pakan meninggalkan rumen. Bahan pakan yang mengandung serat kasar tinggi sukar dicerna sehingga kecepatan alirannya rendah (Susanti dan Marhaeniyanto, 2007). BETN merupakan karbohidrat yang dapat larut meliputi monosakarida, disakarida dan polisakarida yang mudah larut sehingga memiliki daya cerna tinggi.

Nilai manfaat suatu bahan pakan dapat diketahui melalui percobaan kecernaan pada ternak. Kecernaan nutrien merupakan salah satu tolok ukur dalam menentukan kualitas bahan pakan. Kecernaan bahan kering pada ruminansia termasuk kecernaan serat kasar dan BETN menunjukkan tingginya zat makanan yang dapat dicerna pada rumen. Sondakh et al. (2018) menyatakan bahwa semakin tinggi prosentase kecernaan bahan kering suatu bahan pakan menunjukkan semakin tinggi pula kualitas bahan pakan tersebut. Biasanya kecernaan bahan organik lebih tinggi dibandingkan dengan nilai kecernaan bahan kering (Riswandi et al., 2015; Sondakh et al., 2018).
Proses pencernaan makanan dalam rumen terutama dilakukan oleh mikroba sehingga rumen membutuhkan kondisi optimum agar bakteri mampu melakukan aktivitas dengan baik pada kondisi tersebut kecernaan ransum yang dikonsumsi akan meningkat baik (Wahyuni, 2014) Untuk mengetahui kecernaan pakan dalam saluran pencernaan, ada beberapa metode pengukuran kecernaan pada ternak ruminansia yaitu, in vitro, in sacco dan in vivo. In vivo adalah metode yang paling tepat untuk mengetahui konsumsi dan kecernaan suatu bahan pakan karena dilakuakan pengukuran langsung pada ternak.

Berdasarkan uraian diatas maka perlu dilakukan penelitian tentang kecernaan serat kasar dan BETN ransum komplit berbasis tebon jagung pada sapi peranakan ongole. Penelitian ini bertujuan untuk mengetahui kecernaan serat kasar dan BETN ransum komplit pada sapi PO yang menggunakan tebon jagung, rumput raja dan konsentrat.

\section{MATERI DAN METODE PENELITIAN}

Penelitian ini dilaksanakan di UPTD Balai Benih Ternak Desa Tampusu Kec. Remboken. Penelitian ini menggunakan sapi PO sebanyak 14 ekor dengan umur 1,5 - 2 tahun dan bobot badan 
180 - $250 \mathrm{~kg}$. Kandang yang digunakan adalah kandang individual sebanyak 14 kandang yang dilengkapi dengan tempat pakan dan tempat minum.

Pakan yang akan digunakan dalam penelitian terdiri dari pakan penguat (konsentrat) dan pakan hijauan. Pakan konsentrat disusun dari bahan-bahan pakan, yaitu : jagung, dedak halus, bungkil kedelai, bungkil kelapa, tepung ikan, premix (suplemen, vitamin, mineral) dan garam. Pakan hijauan yang digunakan adalah rumput raja dan tebon jagung. Penggunaan $50 \%$ baik pakan penguat maupun hijauan didasarkan pada kebutuhan sapi PO dengan bobot badan berkisar antara $200-300 \mathrm{~kg}$ dimana kebutuhan $\mathrm{BK}$ adalah $7 \mathrm{~kg}$ (Raiyburn, 2009; disitasi dari NRC, 2000). Komposisi nutrisi dari semua bahan pakan yang digunakan serta formulasi ransum penelitian dapat dilihat pada Tabel 1 dan 2 .

\section{Metode Penelitian}

Penelitian ini menggunakan metode eksperimen yang terdiri dari 2 perlakuan dimana masing-masing perlakuan terdiri dari 7 ulangan. Perlakuan yang diterapkan adalah:

Ra 50\% Konsentrat $+50 \%$ Tebon Jagung $\mathrm{Rb} 50 \%$ Konsentrat + 25\% Rumput Raja + 25\% Tebon Jagung

\section{Tatalaksana Penelitian}

Penelitian ini dibagi menjadi 3 tahap yaitu tahap adaptasi, tahap pra koleksi dan tahap koleksi.

1. Tahap pendahuluan

Pada awal penelitian ternak diberikan kesempatan untuk beradaptasi dengan pakan perlakuan. Adaptasi pakan dilakukan selama 7 hari. Adaptasi dilakukan dengan tujuan untuk membiasakan ternak mengkonsumsi pakan perlakuan dan mengetahui konsumsi pakan bebasnya, dimana dilakukan pengambilan data konsumsi. Pakan diberikan secara ad libitum serta air minum disediakan setiap saat, sebelum diberikan ke ternak rumput raja dan tebon jangung dicacah (chopper) terlebih dahulu dengan ukuran $\pm 5 \mathrm{~cm}$ kemudian konsumsi ternak dihitung dari kemampuan ternak mengkonsumsi bahan kering.

2. Tahap prakoleksi

Dua hari sebelum pengambilan data koleksi, dilakukan pembatasan pemberian pakan sebanyak $80 \%$ dari rataan konsumsi pakan pada tahap prelin. Pembatasan pakan dilakukan agar pakan yang diberikan dapat dikonsumsi secara keseluruhan dan tidak tersisa.

3. Tahap koleksi

Pada tahap ini, pakan tetap diberikan sebanyak $80 \%$. Feses ditimbang setiap defikasi dan diambil sampel 5\% untuk analisis. Pengumpulan feses dilakukan selama 5 hari begitu juga dengan 
Tabel 1. Komposisi nutrien bahan pakan penelitian

\begin{tabular}{lccc}
\hline \multirow{2}{*}{ Nutrien } & Konsentrat & Tebon Jagung* & Rumput Raja** \\
\cline { 2 - 4 } & \multicolumn{3}{c}{$\%$} \\
\hline Bahan Kering & 87,93 & 19,73 & 20,30 \\
Protein & 16,65 & 10,90 & 9,52 \\
Lemak Kasar & 10,75 & 2,17 & 3,14 \\
Serat Kasar & 11,23 & 33,21 & 31,26 \\
NDF & 27,23 & 69,81 & 73,52 \\
ADF & 14,39 & 40,20 & 44,49 \\
Ca & 0,73 & 0,39 & 0,35 \\
P & 0,82 & 0,23 & 0,28 \\
Abu & 9,11 & 7,67 & 9,38 \\
BETN & 40,48 & 46,05 & 44,98 \\
Energi Bruto (Kkal) & 3708,89 & 3791,00 & 3375,00 \\
\hline
\end{tabular}

*) Menurut Tulung et al. (2020)

**) Hasil Analisa Lab. Nutrisi dan Makanan Ternak Fak. Peternakan UB (2019)

Tabel 2. Pakan Perlakuan dan Komposisi Nutrien

\begin{tabular}{lcc}
\hline \multirow{2}{*}{ Bahan Pakan *) } & \multicolumn{2}{c}{ Perlakuan } \\
\cline { 2 - 3 } & $\mathrm{Ra}$ & $\mathrm{Rb}$ \\
\hline Konsentrat & 50 & 50 \\
Tebon Jagung & 50 & 25 \\
Rumput Raja & 0 & 25 \\
\hline Total & 100 & 100 \\
\hline & & \\
Komposisi Zat Makanan (\%) & & \\
Protein & 13,77 & 6,69 \\
Lemak & 6,45 & 21,73 \\
Serat Kasar & 22,22 & 43,00 \\
BETN & 43,27 & 8,82 \\
Abu & 8,39 & 3645,95 \\
Energi Bruto (Kkal) & 3749,95 & \\
\hline
\end{tabular}

*) Dihitung berdasarkan Tabel 1 
pengambilan sampel pakan. Pada periode ini diambil sampel pakan. Sampel pakan dan feses akan dianalisis di laboratorium. Analisis kecernaan serat kasar dan BETN dilakukan sesuai petunjuk proksimat.

\section{Variabel Pengukuran}

1. Konsumsi serat kasar

Konsumsi SK = Jumlah SK yang diberikan - Jumlah SK sisa

2. Konsumsi bahan ekstrak tanpa nitrogen (BETN)

Konsumsi BETN = Jumlah BETN yang diberikan - Jumlah BETN sisa

3. Kecernaan Serat Kasar (SK)

Rumus Perhitungan :

Kecernaan SK

$=\frac{\text { Konsumsi SK }- \text { SK Feses }}{\text { Konsumsi SK }} \times 100 \%$

4. Kecernaan Bahan Ekstrak Tanpa Nitrogen (BETN)

Rumus Perhitungan :

Kecernaan BETN

$=\frac{\text { Konsumsi BETN }- \text { BETN Feses }}{\text { Konsumsi BETN }} \times 100 \%$

\section{Analisis Data}

Penelitian ini menggunakan analisis uji $\mathrm{T}$ dua contoh dengan ragam tidak sama (t-test two sample assuming unequal varience) (Snedecor dan Cochran, 1989; Derrick et al. 2017).

\section{HASIL DAN PEMBAHASAN}

Hasil penelitian tentang kecernaan Serat Kasar dan BETN ransum komplit berbasis tebon jagung pada sapi PO dapat dilihat pada Tabel 3.

\section{Konsumsi serat kasar}

Rerata konsumsi Serat Kasar pada penelitian ini adalah 1,11 $\mathrm{kg}$ /ekor/hari pada perlakuan Ra dan 1,13 kg/ekor/hari pada perlakuan Rb. Hasil analisis uji $\mathrm{T}$ menunjukkan bahwa konsumsi serat kasar perlakuan Ra berbeda tidak nyata $(\mathrm{P}>0,05)$ dengan perlakuan $\mathrm{Rb}$. Kandungan serat kasar yang relatif sama menyebabkan konsumsi serat kasar tidak berbeda antara perlakuan $\mathrm{Ra}$ dan perlakuan $\mathrm{Rb}$. De Carvalho et al. (2010) menyatakan kandungan serat kasar dalam pakan yang digunakan sangat berpengaruh terhadap konsumsi serat kasar. Komposisi serat kasar yang terlalu tinggi, dapat menurunkan tingkat konsumsi dan jika komposisi serat kasar terlalu rendah berdampak buruk bagi aktivitas fermentasi dalam rumen.

\section{Konsumsi BETN}

Rerata konsumsi BETN pada penelitian ini adalah 2,3 kg/ekor/hari 
Tabel 3. Nilai Rerata Konsumsi dan Kecernaan Serat Kasar dan BETN Ransum Komplit Tebon Jagung Pada Ternak Sapi PO.

\begin{tabular}{lcc}
\hline \multirow{2}{*}{ Parameter } & \multicolumn{2}{c}{ Perlakuan } \\
\cline { 2 - 3 } & $\mathrm{Ra}$ & $\mathrm{Rb}$ \\
\hline Konsumsi serat kasar (kg/ekor/hari) & 1,11 & 1,13 \\
Konsumsi BETN (kg/ekor/hari) & $2,31^{\mathrm{a}}$ & $2,36^{\mathrm{b}}$ \\
Kecernaan serat kasar (\%) & $63,63^{\mathrm{a}}$ & $73,90^{\mathrm{b}}$ \\
Kecernaan BETN (\%) & $73,85^{\mathrm{a}}$ & $78,55^{\mathrm{b}}$
\end{tabular}

Keterangan : Superskrip berbeda pada baris yang sama menunjukan perbedaan yang nyata $(\mathrm{P}<0,01)$.

pada perlakuan $\mathrm{Ra}$ dan 2,36 kg/ekor/hari pada perlakuan $\mathrm{Rb}$. Hasil analisis uji $\mathrm{T}$ menunjukkan bahwa konsumsi BETN perlakuan $\mathrm{Rb}$ berbeda nyata dengan $(\mathrm{P}<0,05)$ perlakuan Ra. Konsumsi BETN dalam penelitian ini sejalan dengan konsumsi bahan kering (BK) dimana konsumsi BK pada perlakuan $\mathrm{Rb}(5,52$ $\mathrm{kg} /$ ekor/hari) nyata lebih tinggi dibanding perlakuan $\mathrm{Ra} \quad(5,39 \mathrm{~kg} / \mathrm{ekor} / \mathrm{hari})$. Konsumsi BETN pada perlakuan $\mathrm{Rb}$ nyata lebih tinggi dibanding perlakuan $\mathrm{Ra}$ disebabkan kecernaan BETN pada perlakuan $\mathrm{Rb}(78,55 \%)$ nyata lebih tinggi dibanding perlakuan RA $(73,85 \%)$. Semakin tinggi kecernaan maka laju alir pakan keluar dari rumen lebih cepat menyebabkan rumen lebih cepat kosong sehingga konsumsi meningkat. Menurut Widhiastuti (2009) disitasi oleh Indriani et al. (2013) bahwa tingginya daya cerna mempercepat laju aliran pakan di dalam organ pasca rumen dan mengakibatkan lambung cepat kosong. Selanjutnya Tuturoong et al. (2014) menyatakan bahwa laju sintesa mikroba rumen berkorelasi positif dengan ketersediaan karbohidrat mudah dicerna, semakin banyak karbohidrat mudah dicerna dalam pakan yang dikonsumsi, semakin tinggi pula laju sintesa rumen. BETN merupakan fraksi terlarut yang mudah terdegradasi dalam rumen, hal ini berdampak pada tingkat konsumsi. Hadi et al. (2011) menyatakan bahwa pakan yang mengandung fraksi mudah larut rumen akan mudah terdegradasi mikroba rumen, yang akan meningkatkan konsumsi.

\section{Kecernaan Serat Kasar}

Rerata kecernaan serat kasar pada penelitian ini adalah $63,63 \%$ pada 
perlakuan $\mathrm{Ra}$ dan $73,90 \%$ pada perlakuan Rb. Hasil analisis uji $\mathrm{T}$ menunjukkan bahwa kecernaan serat kasar perlakuan $\mathrm{Ra}$ berbeda sangat nyata $(\mathrm{P}<0,01)$ dengan perlakuan $\mathrm{Rb}$. Kandungan serat kasar pada pakan perlakuan $\mathrm{Rb} 21,73 \%$ lebih rendah dibanding $\mathrm{Ra} 22,22 \%$ (Tabel 2). Hal ini menyebabkan kecernaan serat kasar pada perlakuan $\mathrm{Rb}$ lebih tinggi dibanding perlakuan Ra. Menurut Pamungkas et al. (2013) rendahnya kandungan serat kasar akan memudahkan penetrasi mikroba rumen (bakteri, protozoa dan jamur) untuk mencerna nutrien pakan. Artinya semakin rendah kandungan serat kasar dalam pakan semakin tinggi kecernaan serat kasar. Budiman et al. (2006) menyatakan bahwa pasokan energi dan protein pakan dalam jumlah cukup mampu menginisiasi perumbuhan bakteri pencerna serat. Selanjutnya ditambahkan oleh Budiman (2006) bahwa mikroba pencerna serat bukanlah pemakan tunggal terhadap substrat serat semata, akan tetapi dalam kenyaatannya merekapun membutuhkan metabolit lain dari hasil degradasi mikroba lainnya. Meningkatkatnya energi mudah dicerna dan protein akan memperkembangkan bakteri amilolitik dan proteolitik, atau bakteri lainnya lebih luas. Mereka akan memberikan sumbangan metabolit yang dibutuhkan bakteri selulolitik. Selanjutnya Prihantoro et al. (2012) menjelaskan kemampuan bakteri pencerna serat (bakteri selulolitik) mendominasi populasi bakteri dalam rumen sehingga kelompok bakteri pencerna serat berinteraksi secara sinergis antar mikroorganisme di dalam rumen, termasuk dengan bakteri lain yang non selulolitik. Walaupun pada Tabel 2 terlihat bahwa kandungan protein dan energi perlakuan $\mathrm{Ra}$ lebih rendah daripada perlakuan $\mathrm{Rb}$, namun hasil penelitian ini menunjukkan bahwa kecernaan serat kasar pada Rb nyata lebih tinggi dibanding pada perlakuan Ra. Keadaan ini menunjukkan adanya efek asosiasi antar nutrien pakan.

\section{Kecernaan BETN}

Rerata kecernaan BETN pada penelitian ini adalah $73,85 \%$ pada perlakuan Ra dan $78,55 \%$ pada perlakuan Rb. Hasil analisis uji $\mathrm{T}$ menunjukkan bahwa kecernaan BETN perlakuan $\mathrm{Rb}$ berbeda nyata $(\mathrm{P}<0,05)$ dengan perlakuan Ra. Faktor penting yang berpengaruh terhadap kecernaan bahan pakan adalah protein karena berperan dalam menunjung kehidupan mikroorganisme rumen. Komponen BETN terbesar adalah karbohidrat nonstruktural, seperti pati, monosakarida atau gula-gula. Komponen ini banyak banyak terdapat pada bijian cerealia. Budiman et al. (2006) melaporkan bahwa peningkatan protein berpengaruh terhadap penyerapan atau pemanfatan zat- 
zat makanan, sehingga kecernaan BETN cenderung meningkat.

Walaupun kandungan protein dan BETN pada pakan perlakuan $\mathrm{Ra}$ dan $\mathrm{Rb}$ relatif sama (Tabel 2), namun hasil penelitian menunjukkan bahwa kecernaan BETN pada perlakuan $\mathrm{Rb}$ lebih tinggi dari Ra. Hal ini lebih disebabkan oleh adanya efek asosiasi antar nutrien pakan. Kecernaan BETN dalam penelitian ini lebih tinggi dari penelitian Astuti et al. (2009) yang melaporkan bahwa kecernaan BETN ransum yang terdiri dari rumput raja, dedak halus dan konsentrat pada sapi perah berkisar antara 70,69\% - 75,30\%. Hal ini mungkin disebabkan oleh perbedaan kandungan nutrisi pakan.

\section{KESIMPULAN}

Pemberian ransum komplit berbasis tebon jagung pada sapi PO dengan komposisi $50 \%$ konsentrat, 25\% tebon jagung dan $25 \%$ rumput raja meningkatkan konsumsi BETN, kecernaan serat kasar dan kecernaan BETN.

\section{DAFTAR PUSTAKA}

Astuti, A., A. Agus., dan S. P. S. Budhi. 2009. Pengaruh penggunaan High Quality Feed Suplement terhadap konsumsi dan kecernaan nutrien sapi perah awal laktasi. Bulletin Peternakan 33(2): $81-87$.
Biro Pusat Statistik. 2017. Statistik Indonesia. BPS, Jakarta

Budiman, A., T. Dhalika, B. Ayuningsih. 2006. Uji kecernaan serat kasar dan bahan ekstrak tanpa nitrogen (BETN) dalam ransum lengkap berbasis hijauan daun pucuk tebu (Saccharum officanirum). Jurnal Ilmu Ternak 6(2): 132-135

De Carvalho, M. C., Soeparno dan N. Ngadiyono. 2010. Pertumbuhan dan produksi sapi karkas sapi Peranakan Ongole dan Simental Peranakan Ongole jantan yang dipelihara secara feedlot. Buletin Peternakan 34(1): 38-46.

Derrick, B., B. Rush, D. Toher, dan P. White. 2017. Test statistics for the comparison of means for two samples that include both paired and independent observations. Journal of Modern Applied Statistical Methods 16(1): 137-157

Erna, W. dan Sarjiman. 2007. Budidaya hijauan pakan bersama tanaman pangan sebagai upaya penyediaan hijauan pakan di lahan sempit. Jurnal Peternakan dan lingkungan Vol 7: 134-141.

Hadi, R. F., Kustantinah, dan H. Hartadi. 2011. Kecernaan In Sacco hijauan leguminosa dan hijauan non leguminosa dalam rumen sapi Peranakan Ongole. Buletin Peternakan 35(2): 79 - 85 .

Indriani, A. P., A. Muktiani, dan E. Pangestu. 2013. Konsumsi dan produksi protein susu sapi perah laktasi yang diberi suplemen temulawak (Curcuma xanthorrhiza) dan seng proteinat. J. Animal Agriculture 2(1): 128 - 135

Nasriya, Ronny A.V. Tuturoong, Ch. L. Kaunang, S. S. Malalantang, M. M. 
Tindangen. 2016. Pengaruh pemberian rumpu raja (Pennisetum Purpupoides) dan tebon jagung terhadap kecernaan bahan kering dan bahan organik pada sapi PO pedet jantan. Zootec 36(2): 387 394.

NRC. 2000. Nutrient requirements of best of beef cattle. $7^{\text {th }}$ revised Ed., update 200. National Academy Press. Washington DC.

Pamungkas, D., Mariyono, R. Antari, dan T.A. Sulistya. 2013. Imbangan pakan serat dengan penguat yang berbeda dalam ransum terhadap tampilan sapi Peranakan Ongole jantan. Prosiding. Seminar Nasional Teknologi Peternakan dan Venteriner. Hal: 107-115.

Preston, T. R. dan R. A. Leng. 1987. Matching Ruminant Production System with Available Resources in Tropics and Sub-Tropics Panambul Book, Armidale. Australia.

Prihantoro, I., T. Toharmat, D. Evvyernie, Suryani, dan L. Abdullah. 2012. Kemampuan isolat bakteri pencerna serat asal rumen kerbau pada berbagai sumber hijauan pakan. JITV. 17(3):189-200.

Riswandi, Muhakka, dan M. Lehan. 2015. Evaluasi nilai kecernaan serat secara in vitro ransum ternak sapi bali yang disuplementasi dengan probiotik bioplus. Jurnal Peternakan Sriwijaya 4(1): 35-46

Rumiyati. 2008. Pengaruh Imbangan Jerami Kacang Tanah Dengan Rumput Raja Dalam Ransum Terhadap Performan Sapi PFH Jantan. Jurnal Penelitian Ilmu Peternakan Fakultas Pertanian Universitas Sebelas Maret. Vol 9 : 62-68.
Siswanto, D., B. Tulung., K. Maaruf., M. R. Waani dan M. M. Tindangen. 2016. Pengaruh Pemberian Rumput Raja (Pennisetum purpupoides) dan Tebon Jagung Terhadap Kecernaan NDF dan ADF Pada Sapi PO Pedet Jantan. Jurnal Zootek 36(2): 379386.

Snedecor, G. W. dan W. G. Cochran. 1989. Statistical Methods, Eighth Edition, Iowa State University Press.

Soeharsono dan B. Sudaryanto. 2006. Tebon jagung sebagai sumber hijauan pakan ternak strategis di lahan kering Kabupaten Gunung Kidul. Prosiding. Lokakarya Nasional Jejaring Pengembangan Sistem Integrasi Jagung Sapi. Puslitbang Peternakan, Bogor. Hal. $136-141$.

Sondakh, E.H.B., M.R. Waani, J.A.D. Kalele, dan S.C. Rimbing. 2018. Evaluation of dry matter digestibility and organic matter of in vitro unsaturated fatty acid based ration of ruminant. International. J. current adv. Res. 7(6): 13582-13584

Susanti, S. dan E. Marhaeniyanto. 2007. Kecernaan, retensi nitrogen dan hubungannya dengan produksi susu pada sapi peranakan Friesian Holstein (PFH) yang diberi pakan pollard dan bekatul. Jurnal Peternakan 15 : 141-147.

Tulung, Y.L.R., A.F. Pendong, B. Tulung. 2020. Evaluasi nilai biologis pakan lengkap berbasis tebon jagung dan rumput campuran terhadap kinerja produksi sapi Peranakan Ongole (PO). Zootec 40(1): $363-379$

Tuturoong, R.A.V., Hartutik, Soebarinoto, Ch. Kaunang. 2014. Evaluasi Nilai Nutrisi Rumput Benggala Teramoniasi dan Ampas Sagu 
Terfermentasi Dalam Pakan Komplit Terhadap Penampilan Kambing Kacang. Disertasi. Fakultas Peternakan Universitas Brawijaya, Malang.

Wahyuni, I. M. D., A. Muktiani., dan M. Christiyanto. 2014. Kecernaan Bahan Kering dan Bahan Organik dan Degrabilitas Serat pada Pakan yang Disuplementasi Tanin dan Saponin. Agripet. 14(2): 115-124. 